\title{
Evidence that a tax on sugar sweetened beverages reduces the obesity rate: a meta-analysis
}

\author{
Maria A Cabrera Escobar ${ }^{1}$, J Lennert Veerman², Stephen M Tollman ${ }^{1,3}$, Melanie Y Bertram ${ }^{1}$ and Karen J Hofman ${ }^{1,3^{*}}$
}

\begin{abstract}
Background: Excess intake of sugar sweetened beverages (SSBs) has been shown to result in weight gain. To address the growing epidemic of obesity, one option is to combine programmes that target individual behaviour change with a fiscal policy such as excise tax on SSBs. This study evaluates the literature on SSB taxes or price increases, and their potential impact on consumption levels, obesity, overweight and body mass index (BMI). The possibility of switching to alternative drinks is also considered.

Methods: The following databases were used: Pubmed/Medline, The Cochrane Database of Systematic Reviews, Google Scholar, Econlit, National Bureau of Economics Research (NBER), Research Papers in Economics (RePEc). Articles published between January 2000 and January 2013, which reported changes in diet or BMI, overweight and/or obesity due to a tax on, or price change of, SSBs were included.

Results: Nine articles met the criteria for the meta-analysis. Six were from the USA and one each from Mexico, Brazil and France. All showed negative own-price elasticity, which means that higher prices are associated with a lower demand for SSBs. Pooled own price-elasticity was -1.299 (95\% Cl: -1.089- -1.509). Four articles reported cross-price elasticities, three from the USA and one from Mexico; higher prices for SSBs were associated with an increased demand for alternative beverages such as fruit juice $(0.388,95 \% \mathrm{Cl}: 0.009-0.767)$ and milk $(0.129,95 \% \mathrm{Cl}:-0.085-$ 0.342), and a reduced demand for diet drinks (-0.423, 95\% Cl: $-0.628--1.219)$. Six articles from the USA showed that a higher price could also lead to a decrease in BMI, and decrease the prevalence of overweight and obesity.

Conclusions: Taxing SSBs may reduce obesity. Future research should estimate price elasticities in low- and middleincome countries and identify potential health gains and the wider impact on jobs, monetary savings to the health sector, implementation costs and government revenue. Context-specific cost-effectiveness studies would allow policy makers to weigh these factors.
\end{abstract}

Keywords: Obesity, Fiscal policy, Tax, Non-communicable diseases (NCDs), High income countries, Middle income countries, Sugar Sweetened Beverages (SSBs), Elasticity, Demand, Price

\section{Background}

Obesity is a global epidemic and is a major risk factor for the growing burden of non-communicable diseases (NCDs) including heart diseases, diabetes and some cancers $[1,2]$. Although previously considered a problem of

\footnotetext{
* Correspondence: Karen.Hofman@wits.ac.za

'PRICELESS SA (Priority Cost Effective Lessons in System Strengthening South Africa), Johannesburg, South Africa

${ }^{3}$ Wits/Medical Research Council Rural Health and Health Transitions Unit,

School of Public Health, Faculty of Health Sciences, University of

Witwatersrand, Johannesburg, South Africa

Full list of author information is available at the end of the article
}

high income countries (HICs), NCDs are now having a major impact on the economy of low and middle income countries (LMICs) [3]. In the past three decades there have been considerable changes in lifestyle around the world, helped along by globalisation of the food supply and urbanisation [4]. These changes affect diet and decrease levels of physical activity, thereby increasing body mass index (BMI) [5]. The Global Burden of Disease (GBD) study (2010) shows an increased share of noncommunicable diseases in adults over the period from 1990 to 2010, both globally and in each region [6]. Dietary

\section{Biomed Central}

(c) 2013 Cabrera Escobar et al.; licensee BioMed Central Ltd. This is an open access article distributed under the terms of the Creative Commons Attribution License (http://creativecommons.org/licenses/by/2.0), which permits unrestricted use, distribution, and reproduction in any medium, provided the original work is properly cited. 
risk factors (including low intake of fruits, vegetables, whole grains, nuts and seeds, and omega- 3 fatty acids) and physical inactivity are estimated to be responsible for ten percent of the global health loss, expressed as disability-adjusted life years [6].

Middle income countries, in particular, face many challenges given far-reaching epidemiological and demographic transitions underway $[7,8]$. For example, South Africa reported the highest prevalence of people classified as overweight or obese (29\% of men and $56 \%$ of women) of all countries in Africa [9]. Data from the National Burden of Disease Study in South Africa show that NCDs were responsible for $28 \%$ of the disease burden in 2004, which is similar in magnitude to the HIV/AIDS burden [10].

Worldwide, despite lifestyle change programmes to prevent obesity, this epidemic is growing. Interest is mounting in developing combined approaches to address individual behaviour change together with population-oriented fiscal policies such as tax and subsidies to encourage healthier food consumption patterns. For example, in Hungary, a "fat tax" is part of a fiscal policy to address the obesity epidemic [11]. Several states in the USA have also introduced an excise tax on sugar sweetened beverages (SSBs), the original intention being to raise revenue, but this is now considered as anti-obesity policy [12]. While many studies to date come from HICs, there is limited information in the published literature regarding legislative and fiscal changes policy in LMICs.

Various categories of food products have been recommended for policy action to improve health. These include processed food (high in salt, sugar and fat), high energy density food (energy density refers to the amount of energy in a given weight of food in $\mathrm{kcal} / \mathrm{g}$ or $\mathrm{kJ} / \mathrm{g}$ ) [13], fast food, food containing saturated fat, junk food and soft drinks [14]. In South Africa, legislation has now been passed to regulate salt in processed food $[15,16]$. With respect to obesity, an effective starting point to diminish unhealthy food consumption might be through taxing of SSBs [17]. The application of an excise tax on these products is an attractive option because, while SSBs are a significant contributors to the energy intake in many populations (for example, they account for about $7 \%$ of all calories consumed in the US [18]; whereas for US children and adolescents this is $11 \%$ [19]) they provide little or no nutritional value [20-23]. Further, SSBs are marketed aggressively [24] and are easily accessible to all age groups through vending machines, restaurants, schools, cafeterias and shops, as well as at home $[25,26]$. A recent review concludes that "the cumulative evidence from observational studies and experimental trials is sufficient to conclude that regular consumption of SSBs causes excess weight gain" [19].

The link between intake of SSBs and obesity-related health outcomes is well established [27-29], as is the link between the intake of SSBs and conditions such as osteoporosis [30] and dental caries [28]. From an early age this poses a risk of low nutrient intake because children tend to substitute SSBs for healthier drinks [28,31]. A range of clinical trials and cohort studies provide evidence for a causal association between the intake of SSBs and obesity [32]. It is possible that a subgroup of individuals with a greater genetic predisposition may be more susceptible to obesity induced by SSBs [29].

Interventions outside the health care system can have a significant impact on a nation's health, as recognised in WHO's 'health-in-all-policies' framework [33]. Small changes in diet for many individuals can translate into large population health gains at relatively low cost [34] and government finance departments in particular can improve population health by establishing incentives and disincentives to drive change throughout the food system, including consumer purchases [35]. If government departments that do not have health as their primary responsibility are to consider health-promoting interventions, evidence on the effectiveness of those options is needed [36].

This review evaluates the published evidence for SSB taxes or price increases, and their potential impact on consumption levels and effects on obesity, overweight and BMI. The possibility of switching to alternative drinks is also considered. Two previous studies have reported pooled estimates of price elasticities in the consumption of SSBs, but both were restricted to data from the US $[37,38]$. The present study will also include nonUS studies, and so contribute to the evidence base on the contribution that SSB taxation can make to improving diets and health around the world.

\section{Methods}

A systematic literature review was conducted, including original research articles, working papers, and editorials related to SSBs. Articles published between January 2000 and January 2013 were selected.

Many terms are used to describe SSBs. These include soft drinks, sugary drinks, non-alcoholic drinks, soda, sweet drinks, beverage, fruit drinks, sport drinks, cold drinks and carbonated SSBs. Other beverages including full cream milk, low-fat milk, skim milk, water, tea and coffee were excluded. These drinks may contain some nutritional value and none of them contain sugar added prior to packaging, so their relationship with obesity is not as direct it is for SSBs.

The inclusion criteria were articles in English from any country, with original evidence on the quantitative impact of SSB price changes on the consumption of SSBs, consumption of other drinks, or weight loss, obesity or BMI. For the meta-analysis, we excluded articles that did not report standard error or confidence interval on the 
own-price elasticity and/or cross-price elasticity. Articles that did not clearly define the type of SSBs were also excluded.

Figure 1 shows the literature search according to the following key words and databases:

Key words searched were: "nutrition AND policy AND tax", "legislation AND obesity", "tax food", "elasticity of demand", "policy AND "soft drink"”, "policy AND "fast food"”, "food AND prices", "elasticity AND nutrition", and "fat tax".

Databases used were: Pubmed/Medline, The Cochrane database of systematic reviews, Google Scholar, EconLit (AEA), National Bureau of Economics Research (NBER), and Research Papers in Economics (RePEc).

The first author carried out the search, applied the inclusion criteria and extracted the data, in frequent consultation with a second researcher (JLV). We used an
MS Excel-based data extraction form that was piloted on a subset of the data and subsequently revised. The following quantitative results were extracted: own-price elasticity (percentage change in quantity demanded and standard error), cross price elasticity (percentage change in quantity demanded and standard error) (see Table 1 definitions) $[39,40]$, or impact on obesity (percentage points and standard error), overweight (percentage points and standard error) or BMI ( $\mathrm{kg} / \mathrm{m} 2$ and standard error), due to a tax or price change on SSBs. If the data was presented in other metrics values, this was changed to the metrics value of interest using the BMI and cross-price elasticity formula. If the articles lacked certain data or if the analyses were unclear, the authors were contacted for additional information or clarification.

Meta-XL, a tool for meta-analysis in Microsoft Excel, was used to synthesize results for own- and cross-price

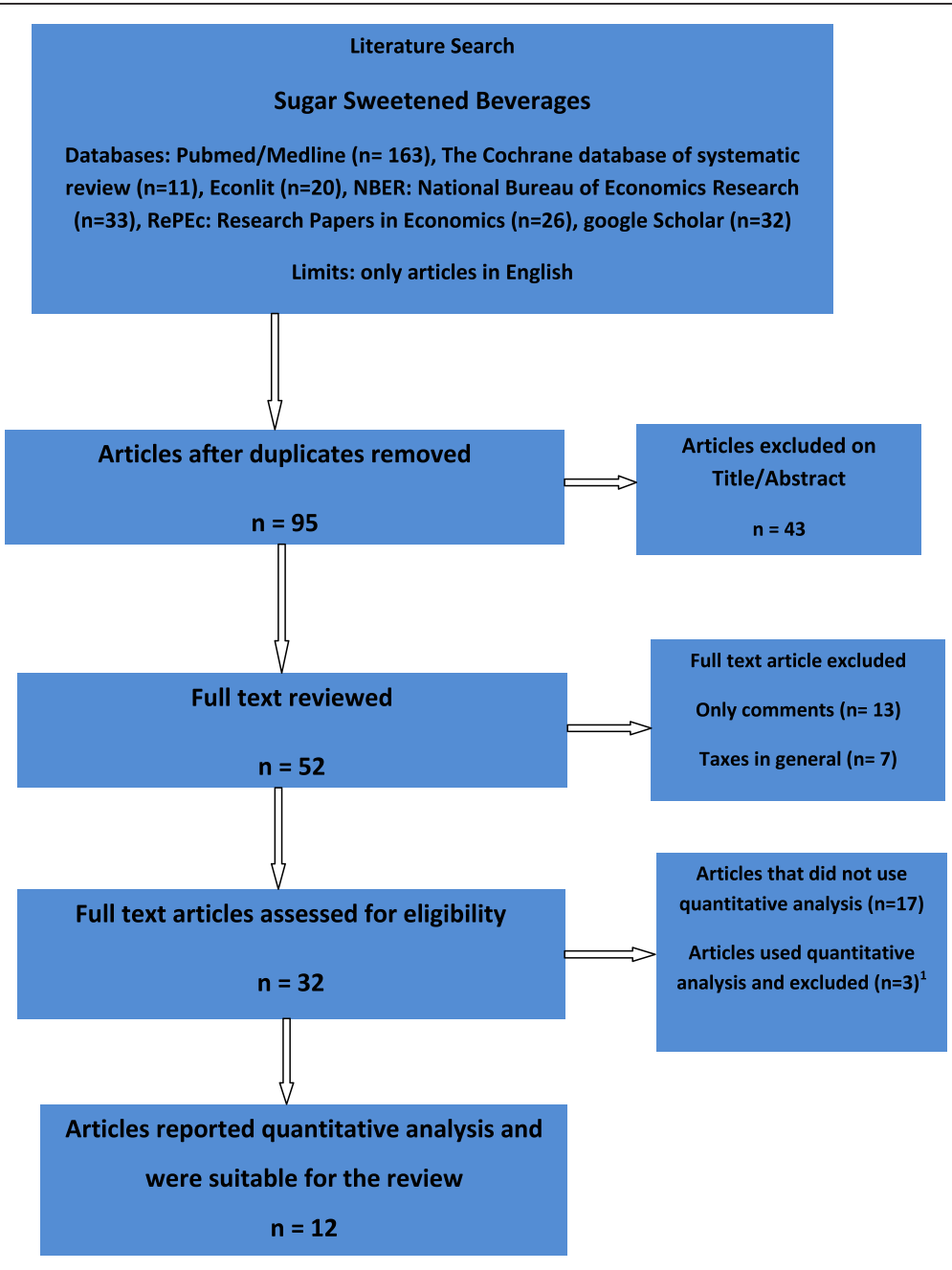

${ }^{1}$ Three articles were excluded on the basis of missing data (did not report standard error and the definition of SSBs was not clear).

Figure 1 Literature search. 


\section{Table 1 Definition of price elasticity}

\section{Own-price elasticity}

To estimate the impact of taxes on specific foods, it is important to know just how responsive quantity demanded is to change in price. "Own-price elasticity" is an index that expresses this responsiveness. It is the ratio of the percentage change in quantity demanded to the percentage change in price. This should be negative, because the demand for certain products normally decreases as its price increases. If the own-price elasticity is greater than the absolute value of 1 , the demand is called 'elastic'. If it is less than 1, demand is inelastic $[39,40]$.

\section{Cross-price elasticity}

A related concept is'cross-price elasticity', which measures the change in the quantity demanded of one good in response to a change in the price of another good. It can be either positive or negative. Positive cross-price elasticity indicates that an increase in the price of $X$ causes the demand for $Y$ to rise. This implies that the goods are substitutes. A negative cross-price elasticity indicates that an increase in the price of $X$ causes a decrease in the demand for $Y$, which implies that the goods are complements [39,40]

Table 2 Characteristics of the 12 articles in the meta- analysis and the impact on obesity, overweight and BMI

\begin{tabular}{|c|c|c|c|c|}
\hline Author & Population (n) & Dataset & Type of SSBs & $\begin{array}{c}\text { Independent } \\
\text { variable }\end{array}$ \\
\hline \multirow{5}{*}{$\begin{array}{l}\text { Barquera S, et al. [44], } \\
\text { Mexico }\end{array}$} & 1) Adolescents $(n=416)$ & 1) Mexican Nutrition Survey Adolescents, 1999 & Soda & Price \\
\hline & Adults $(n=2180)$ & 2) Mexican Health and Nutrition Survey, 2006 & & \\
\hline & 2) Adolescents $(n=7464)$ & \multirow{3}{*}{$\begin{array}{l}\text { 3) The Mexican household income and } \\
\text { expenditure surveys, 1989, } 1998 \text { and } 2006\end{array}$} & Sweet drinks & \\
\hline & Adults $(n=21113)$ & & & \\
\hline & $\begin{array}{l}\text { 3) Household ( } n=12000 \\
\text { to } 20000)\end{array}$ & & & \\
\hline \multirow{2}{*}{$\begin{array}{l}\text { Bonnet C, et al. [45], } \\
\text { France }\end{array}$} & \multirow[t]{2}{*}{ Household $(n=19000)$} & Consumer panel data & Soft drink & Price \\
\hline & & 2003-2005 & & \\
\hline \multirow{2}{*}{$\begin{array}{l}\text { Claro RS, et al. [46], } \\
\text { Brazil }\end{array}$} & All ages & Household food consumption data & \multirow[t]{2}{*}{ SSB } & \multirow[t]{2}{*}{ Price } \\
\hline & $(n=48470)$ & $2002-2003$ & & \\
\hline \multirow{2}{*}{$\begin{array}{l}\text { Dharmasena S, et al. } \\
\text { [42], USA }\end{array}$} & \multirow[t]{2}{*}{ Household } & Nielsen Homescan Panel & \multirow{2}{*}{$\begin{array}{l}\text { Non-alcoholic } \\
\text { beverage }\end{array}$} & \multirow[t]{2}{*}{$\operatorname{Tax}$} \\
\hline & & 1998 to 2003 & & \\
\hline \multirow{2}{*}{$\begin{array}{l}\text { Finkelstein EA, et al. } \\
{[18], \text { USA }}\end{array}$} & Household & Nielsen Homescan panel & Carbonated SSBs & \multirow[t]{2}{*}{ Price } \\
\hline & $(n=384252)$ & 2006 & All SSBS & \\
\hline \multirow{2}{*}{$\begin{array}{l}\text { Finkelstein EA, et al. } \\
\text { [47] USA }\end{array}$} & \multirow[t]{2}{*}{ Adults and children } & Nielsen Homescan panel & \multirow[t]{2}{*}{ SSBS } & \multirow[t]{2}{*}{ Price } \\
\hline & & 2006 & & \\
\hline $\begin{array}{l}\text { Fletcher JM, et al. } \\
{[12], \text { USA }}\end{array}$ & Ages $>18$ & $\begin{array}{l}\text { Behavioral Risk Factor Surveillance System } \\
1990-2006\end{array}$ & Soft drink & $\operatorname{Tax}$ \\
\hline $\begin{array}{l}\text { Fletcher JM, et al. [48], } \\
\text { USA }\end{array}$ & Ages 3 to $18(n=34000)$ & NHANES 1989 and 2006 & Soft drinks & $\operatorname{Tax}$ \\
\hline \multirow[t]{2}{*}{$\begin{array}{l}\text { Han E and Powell LM. } \\
\text { [23], USA }\end{array}$} & $\begin{array}{l}\text { Follow-up after high school } \\
\text { graduation }\end{array}$ & Monitoring the Future Surveys & \multirow[t]{2}{*}{ Soft drink } & \multirow[t]{2}{*}{ Price } \\
\hline & $(n=2400)$ & $1992-2003$ & & \\
\hline \multirow[t]{4}{*}{ Lin BH, et al. [49], USA } & Household $(n=22750)$ & Nielsen National Consumer Panel & Sugary drinks & \multirow[t]{4}{*}{ Price } \\
\hline & $\begin{array}{l}\text { Children 2-19 }(n=7291 \\
\text { Children) }\end{array}$ & 1998-2007 & Diet drinks & \\
\hline & \multirow[t]{2}{*}{$\begin{array}{l}\text { Adults } 20 \text { and older } \\
(n=8322)\end{array}$} & $\begin{array}{l}\text { National Health and Nutrition Examination } \\
\text { Survey }\end{array}$ & \multirow[t]{2}{*}{ Juices } & \\
\hline & & 2003-2006 & & \\
\hline \multirow[t]{3}{*}{$\begin{array}{l}\text { Powell LM, et al. [21], } \\
\text { USA }\end{array}$} & $\begin{array}{l}\text { Students from 8th - 10th } \\
\text { grade }\end{array}$ & \multirow{3}{*}{$\begin{array}{l}\text { Monitoring the future Survey combined with } \\
\text { state-level tax data and local area contextual } \\
\text { measure 1997-2006 }\end{array}$} & \multirow[t]{3}{*}{$\begin{array}{l}\text { Vending machine } \\
\text { soda }\end{array}$} & \multirow[t]{3}{*}{$\operatorname{Tax}$} \\
\hline & 12000 - 15000 Students & & & \\
\hline & $\begin{array}{l}\text { from 12th grade } \\
(n=30000)\end{array}$ & & & \\
\hline \multirow{2}{*}{$\begin{array}{l}\text { Smith TA, et al. [50] } \\
\text { USA }\end{array}$} & & Nielsen Homescan panelists & \multirow{2}{*}{$\begin{array}{l}\text { Caloric sweetened } \\
\text { beverages }\end{array}$} & \multirow[t]{2}{*}{ Price } \\
\hline & & $1998-2007$ & & \\
\hline
\end{tabular}


elasticities using the random effects model (http://www. epigear.com). A funnel plot test was performed to check for possible bias in the own-price elasticities incorporated in the meta-analysis. The studies reporting weight outcomes were too heterogeneous to be pooled.

\section{Results}

Figure 1 shows the results of the literature search. First, of 95 articles related to SSBs, 43 were excluded as the title or abstract indicated that the article was not related to fiscal or legislative policies. Second, out of the 52 full text articles reviewed, 20 were excluded because they only commented on SSBs (without mention of any policy) or discussed taxes in general (not directly related with SSBs).

Of the remaining 32 articles, 15 presented quantitative data and the remaining 17 reported qualitative data (Figure 1). Three further articles were excluded on the basis of missing data (did not report standard error and the definition of SSBs was not clear). These three studies were performed in Germany [41] and two in the USA [42,43].

The twelve articles that qualified for our analysis reported own-price elasticity, cross price elasticity, or impact on obesity, overweight or BMI. Nine articles met the criteria for the meta-analysis (Table 2). The remaining three articles reported only the impact of SSB price on BMI, overweight and/or obesity. All primary data consisted of either cross sectional or longitudinal studies. There were no intervention studies. The studies were from four countries: USA, France, Mexico and Brazil. All were published between 2008 and 2013.

Table 3 shows ten estimates of own-price elasticity reported in nine of the studies: six from the USA [18,47-51] and one each from Mexico [44], Brazil [46] and France [45]. Of the studies performed in the USA, two used tax data and four price data, while the studies performed in Mexico, Brazil and France used price data. All the results show negative elasticity, which means that an increase in price was associated with a decrease in the demand for SSBs. Of the studies done in middle income countries, the one in Brazil showed an elasticity of -0.85 [46] and the one in Mexico, -1.085 [44]. The results from the metaanalysis show that the pooled elasticity estimate is -1.30 (95\% CI: $-1.089--1.509$ ). The funnel plot (Figure 2) for the own-price elasticities in the meta-analysis was roughly symmetric, which provides no indication of publication bias.

Table 3 also shows cross-price elasticities from the USA [49,50] and Mexico [44] Generally, the consumption of SSBs was compared with whole milk, fruit juices and diet soft drinks. The demand for these products was affected by SSBs prices. For fruit juices, the metaanalysis shows a cross-price elasticity of 0.388 (95\% CI: $0.010-0.767)$, for whole milk a cross-price elasticity of 0.129 ( $95 \%$ CI: $-0.085-0.342)$ and for diet soft drinks the

Table 3 Own and cross price elasticity of SSBs

\begin{tabular}{|c|c|c|c|c|c|c|c|c|}
\hline \multirow[t]{2}{*}{ Author/year/country } & \multicolumn{2}{|c|}{ Own-price elasticity } & \multicolumn{6}{|c|}{ Cross-price elasticity } \\
\hline & Estimated & SE & Fruit juice & SE & Whole milk & SE & Diet drink & SE \\
\hline Barquera S, et al. (2008) [44], Mexico & -1.085 & 0.195 & -0.016 & 0.003 & 0.052 & 0.011 & & \\
\hline Bonnet C, et al. (2011) [45], France ${ }^{1}$ & -2.206 & 0.133 & & & & & & \\
\hline Claro RS, et al. (2012) [46], Brazil ${ }^{2}$ & -0.85 & 0.434 & & & & & & \\
\hline Dharmasena S, et al. (2012) [42], USA ${ }^{3}$ & -2.255 & 0.550 & & & & & & \\
\hline Finkelstein EA, et al. (2010) [47], USA & -0.870 & 0.090 & & & & & & \\
\hline Finkelstein EA, et al. (2013) [18], USA & -1.320 & 0.005 & & & & & & \\
\hline Fletcher JM, et al. (2010b) [48], USA ${ }^{4}$ & -4.445 & 1.806 & 1.857 & 2.332 & 7.67 & 2.156 & & \\
\hline Lin BH, et al. (2011) [49], USA (Low-Income Population) & -0.949 & 0.082 & 0.473 & 0.127 & 0.242 & 0.129 & -0.23 & 0.104 \\
\hline Lin BH, et al. (2011) [49], USA (High-Income Population) & -1.292 & 0.096 & 0.529 & 0.093 & -0.054 & 0.13 & -0.591 & 0.112 \\
\hline Smith TA, et al. (2010) [50], USA & -1.264 & 0.089 & 0.557 & 0.095 & 0.222 & 0.126 & -0.457 & 0.103 \\
\hline Overall & \multicolumn{2}{|c|}{-1.299} & \multicolumn{2}{|c|}{0.388} & \multicolumn{2}{|l|}{0.129} & \multicolumn{2}{|c|}{-0.423} \\
\hline$(\mathrm{LCl}-\mathrm{HCl})$ & \multicolumn{2}{|c|}{$(-1.089--1.509)$} & \multicolumn{2}{|c|}{$(0.0095-0.767)$} & \multicolumn{2}{|c|}{$(-0.085-0.342)$} & \multicolumn{2}{|c|}{$(-0.628--1.219)$} \\
\hline
\end{tabular}

In all the next four cases the authors were contacted by email and could not provide any additional information to explain the missing values needed. To enable inclusion of the studies, we estimated the following values:

'Own-price elasticity: Consumer prices rose "by more than $3.4 \%$ on average" which led to a decrease in market share of $7.5 \%$. Then $-7.5 / 3.4=-2.206$. SE was inferred from Table VI: SE $=(-0.07 / 1.16)^{*} 2.206=0.133$.

${ }^{2}$ Information obtained from the paper: $\mathrm{P}<0.05$ at $\mathrm{p}(2$-sides $)=0.05$. Then $\mathrm{SE}=-[0.85] / 1.96=0.434$.

${ }^{3}$ The paper does not report SE, but only a p-value of 0.0000 . It was used a website to derive an estimate of the Z-statistic (http://easycalculation.com/statistics/pvalue-for-z-score.php). It was chose a value of 4.1, which is the lowest value that gives a two-sided $\mathrm{p}$-value of 0.0000 . Then $\mathrm{SE}=-[2.255] / 4.1=0.550$.

${ }^{4} \mathrm{SE}$ inferred from mean and SE of grams of soft drink consumption (Table 4 in ref [48]): mean $=-18.052, \mathrm{SE}=7.333$, Ratio 7.33/-18.052 $=-0.40622$.

Then SE $=-4.445^{*}-0.40622=1.806$.

The numbers in parenthesis denote $95 \%$ confidence interval. 


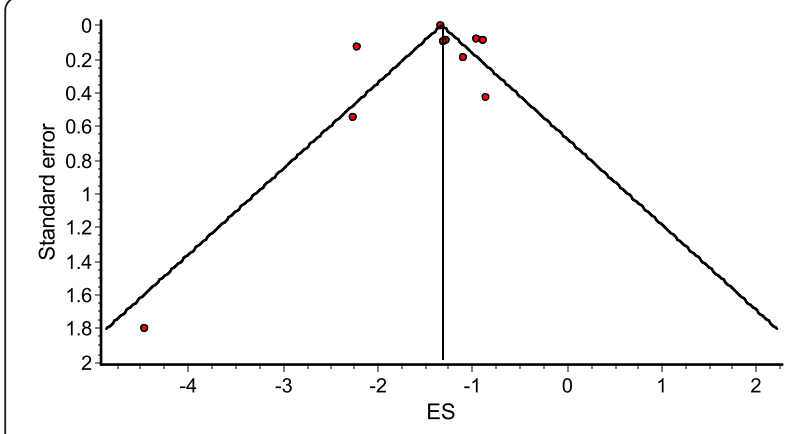

Figure 2 Funnel plot of studies with own-price elasticity of SSBs as outcome.

cross-price elasticity is -0.423 (95\% CI: $-0.628--0.219)$. This means that fruit juices and perhaps whole milk act as substitutes for SSBs $[44,45,52,53]$ and diet soft drinks are consumed in complement to SSBs $[44,48,49]$ (See Table 1 for definitions).

Table 4 shows the impact on BMI, overweight and obesity due to a change in the price of different SSBs. It was not possible to perform a meta-analysis because of differences in interventions, outcomes and populations (e.g. households, individuals - adults, adolescents and children - as well as diverse range of food stores and vending machine outlets). The only available information was from the USA [12,23,47,50,52]. A range of estimates were reported, showing significant discrepancy between results. Han and Powell [52] show that for a $1 \%$ increase in SSB price, the point prevalence for obesity would reduce more in men $(-0.34$ percentage points) than in women $(-0.05)$ [52]. Smith, et al. [50] found a reduction in the pointprevalence of overweight $(-0.045$ percentage points) and obesity ( -0.03 percentage points) in adults [50]. Finkelstein, et al. [18] presents data at household level, for $20 \%$ increase in SSBs price the impact on BMI would be $-0.065 \mathrm{~kg} / \mathrm{m} 2$ [47]. The negative impact on BMI reported by Powell, et al. [23] is for specific taxes: the effect of a grocery soda tax was associated with a BMI increase of $0.012 \mathrm{~kg} / \mathrm{m} 2$ and a tax on soft drinks sold via vending machines with a $0.011 \mathrm{~kg} / \mathrm{m} 2$ increase. These effects were not statistically significant [23]. Fletcher, et al. [12] found a low level of impact in BMI $(-0.0031 \mathrm{~kg} / \mathrm{m} 2)$ for adults and a nonsignificant impact $(-0.015 \mathrm{~kg} / \mathrm{m} 2)$ in children and adolescents $[12,29]$.

\section{Discussion}

This comprehensive literature review suggests that an increase in price of SSBs is associated with a decrease in consumption; and the higher the price increase, the greater the reduction in consumption. Also, as the price of SSBs rises, the consumption of fruit juices and whole milk tends to increase (although the evidence for the latter trend is not statistically significant), and the consumption of diet drinks decreases. The few available studies suggest that higher prices of SSBs may lead to modest reductions in weight in the population.

The intention of this study was to evaluate the available evidence worldwide. The pooled own-price elasticity was -1.30 (Table 3 ). These results are consistent with other meta-analyses including Powell et al. [18,37] which found an own-price elasticity of -1.21 ; and Andreyeva, et al. [38] which found an own-price elasticity of -0.79 . Both of these studies used only USA data. There was insufficient evidence to undertake a separate meta-analysis for LMICs.

The possible reasons for the own-price elasticity outlier results $[45,48]$ include that fact that one of the studies used data from France and the consumption patterns may differ from the USA. Context-specific evidence can however be important because different elasticities could be related to income or consumer preferences.

Several states in the USA have already implemented an excise tax on SSBs, but there is no experience from middle income countries where the SSB market is growing. Research from Mexico [44] and Brazil [46] is based

Table 4 The impact on obesity, overweight and BMI based in consumption change due to price increase of SSBs

\begin{tabular}{|c|c|c|c|c|c|c|c|}
\hline Author/year/country & $\begin{array}{l}\text { Impact on BMI } \\
\mathrm{kg} / \mathrm{m} 2\end{array}$ & SE & $\begin{array}{l}\text { Impact on } \\
\text { overweight }\end{array}$ & SE & $\begin{array}{l}\text { Impact on obesity } \\
\text { prevalence }\end{array}$ & SE & $\begin{array}{c}\text { Price } \\
\text { increase (\%) }\end{array}$ \\
\hline Fletcher JM, et al. (2010a) [12] USA - Adults & -0.0031 & 0.0005 & -0.0002 & 0.0001 & -0.0001 & -0.000 & $1 \%$ \\
\hline $\begin{array}{l}\text { Fletcher JM, et al. (2010b) [48] USA - Children } \\
\text { and adolescents }\end{array}$ & -0.015 & 0.016 & -0.002 & 0.011 & -0.009 & -0.006 & $1 \%$ \\
\hline EA, et al. (2010) [47] USA & $-0.065^{1}$ & 0.023 & & & & & $20 \%$ \\
\hline Han E, et al. (2011) [52], USA - Women & & & & & -0.05 & 0.287 & $10 \%$ \\
\hline Han E and Powell LM. (2011) [52], USA - Men & & & & & -0.34 & 0.381 & $10 \%$ \\
\hline Powell LM, et al. (2009) [21] USA - Vending Machine & 0.011 & 0.017 & & & & & $1 \%$ \\
\hline Powell LM, et al. (2009) [23] USA - Grocery shops & 0.0124 & 0.0124 & & & & & $1 \%$ \\
\hline Smith TA, et al. (2010) [50], USA & & & -0.045 & $N / R$ & -0.03 & $N / R$ & $20 \%$ \\
\hline
\end{tabular}

${ }^{1}$ BMI calculation. Formula: Mass $(\mathrm{kg}) /(\text { Height }(\mathrm{m}))^{\wedge} 2=0.20 \mathrm{~kg} / 1.76 \mathrm{~m}=\mathbf{0 . 0 6 5}$. Mass is $0.20 \mathrm{~kg}$ (Page 5. Table 3. 20\%Tax on carbonated SSBs. All groups). Height: 1.76 (USA average height).

$N / R$ Not reported. 
on modelling a correlation between prices and consumption and provides useful information for middle income countries, since it can be used to assess the impact of taxes. Claro, et al. [46] presented two different own-price elasticities, for poor $(-1.03)$ and non-poor $(-0.63)$ (urban and rural area), which suggests that in Brazil, the poor are more price-sensitive than the more affluent [46].

The evidence from Brazil and Mexico is consistent with evidence from high income countries. This is important information for policy makers in other middle income countries, who can potentially draw on the pooled data until local evidence becomes available.

A surprising finding of the review was that the consumption of diet drinks may decrease as the price of SSBs increases [54]. Several explanations are possible but evidence is scarce. Andreyeva et al. suggest that bottlers and/or retailers could equalise prices between both types of beverages to counteract the tax [43] [REF]. People may consume diet soft drinks in the company of people who consume sweetened soft drinks, and if the price of the latter goes up, both might switch to alternative beverages. Media reports on the negative impact of SSBs that accompany new taxes may change cultural norms not only for SSBs but also for diet drinks, in a sort of 'contamination' effect. Replacing SSBs with sugar-free beverages may not completely avoid health problems. Some studies suggest that the risk of developing metabolic syndrome increases by $34 \%$ with high consumption of diet soda $[55,56]$. In that light, a negative cross-price elasticity would be reassuring. However, although the results of our meta-analysis are statistically significant, the negative cross-price elasticity for diet drinks relies on only three studies, which is not a strong basis for conclusions.

Double-blind, randomised clinical trials in children and adolescents find that drinking sugar-free beverages rather than sugar containing beverages has the potential to significantly reduce weight gain and body fat gain $[32,57]$. There is good evidence of an association between SSB consumption and obesity. In addition, an increase in price of SSBs would likely reduce consumption $[18,44]$. This suggests that taxing SSBs effectively could result in reduced BMI, overweight and obesity among populations. Smith et al. [50] show a decrease in point prevalence for overweight $(-0.045)$ and obesity $(-0.03)$. The authors argue that a minor reduction in caloric intake will change the weight classification of these adults as most of them are marginally overweight or obese. Likewise, adults with a higher weekly or daily consumption would be affected more than those whose consumption is lower. In contrast, an increase in weight was found in the study by Powell, et al. [23] and a modest reduction in weight in the study by Fletcher, et al. [48], but each of these studies raises questions. The positive association between taxes and body weight that Powell, et al.
[23] presented, may be related to the analysis focusing on specific taxes, i.e., a vending machine soda tax rate that appeared associated with a $0.011 \mathrm{~kg} / \mathrm{m} 2$ increase in BMI. Such taxes may not be effective as people may purchase their SSBs via other outlets. Moreover, existing high levels of obesity should have prompted the imposition of taxes on all SSBs rather than on specific vending machine outlets. Fletcher et al. [48] provide some evidence that such a tax may reduce the weight among adolescents at risk of overweight, while there is no observed effect on those with normal weight. One study [48] notes that the impact may be minimal because of substitution with fruit juice and milk. The calories in these beverages could reduce the effect of price increases on SSBs; juice consumption as been associated with weight gain [53]. Even so, a switch to milk and fruit juice would still come with a health gain as these drinks contain calcium and vitamins.

Overall this review suggests that taxing SSBs may benefit health. Potential models for taxing SSBs can be drawn from the tobacco and alcohol excise tax experience. Because SSBs do not provide any nutritional value, and when consumed in excess can be harmful, it seems appropriate to consider a similar approach. This would mean that the tax is levied as a "specific tax" for example an "excise tax", such as a sum per gram of added sugar, raising the net-of-tax price [45]. There are two important reasons for considering a tax on sugar content: Firstly, it would avoid substitution in favour of other products with high sugar content [45] and secondly, it might provide an incentive for industry to reduce the sugar content of SSBs. In contrast, if the tax is an "ad valorem" tax, the specific value of the tax will be based on the cost of the product thus permitting a company to reduce the pre-tax price of their product, hence lowering the tax level and undermining its health impacts (albeit at the expense of profits). SSB price has been shown to have a dose-response relationship with consumption, with higher taxes resulting in greater reduction in SSB calories [45,58,59]. This consumption effect may be mitigated by consumers substituting products such as milk or fruit juice. An alternative option would be to tax all sugar when it leaves the factory or enters a country, using the argument that such a tax may be easier to implement and that sugar consumption in general is higher than is good for health [60]. Chriqui et al. [60] give a useful overview of SSB taxes applied in jurisdictions around the world.

Taxes generate revenue. For example, in the USA, soft drink revenue is approximately $\$ 70$ billion per year, so a modest tax would generate billions of dollars [48]. The revenue from an excise tax could be used to support a variety of obesity reduction programmes, school nutrition programmes, or to finance a Health Promotion Foundation [61] that could advocate for healthy eating including further reductions in the consumption of SSBs. A tax might 
also be used to subsidise alternative healthy drinks to reduce their price and thus encourage consumption $[62,63]$. In areas where people drink SSBs because they do not have access to clean water, ensuring universal access to clean, piped water should be a priority.

One argument against the imposition of an excise tax alone is that it is regressive $[12,49,64]$. Lower-income households tend to spend a greater portion of their income on consumable goods than higher-income households. Relative to income, a SSB tax would therefore affect low-income people more than high-income people. However, low income households, as a group, are also likely to reap greater benefit. To the extent that low-income individuals are more price sensitive, they will be more likely to cut back on the intake of taxed SSBs, often from a higher consumption level and with a higher BMI, and thus experience greater health gain [64]. This gives ground to consider a simultaneous subsidy of healthy foods such as fruit and vegetables. In the past, those most susceptible to obesity and cardiovascular diseases were among the wealthier in the population but this is no longer the case. Low income earners are now a population with high consumption of unhealthy obesogenic food [65,66]. Also in many LMICs, the prevalence of obesity is growing more rapidly in low socioeconomic groups [67]. Upcoming research should estimate price elasticities in low- and middle-income countries and identify potential health gains from taxes combined with subsidies of healthy food.

As far as we know, this is the first global overview of the effect of SSB price on consumption and body weight and, in the absence of good quality local evidence, may inform policy decisions worldwide. The limitations are twofold. First, in LMICs, consumption patterns and price sensitivities may differ from HIC (although the evidence from Mexico and Brazil does not support this). Secondly, the data included in the meta-analysis are from heterogeneous populations with various data sources involving households, individuals (adults, adolescents and children) as well as a diverse range of food stores and vending machine outlets.

\section{Conclusions}

An increase in price of SSBs is associated with a decrease in consumption; and the higher the price increase, the greater the reduction in consumption. Also, as the price of SSBs rises, the consumption of fruit juices and whole milk tends to increase and the consumption of diet drinks decreases. The alternative beverages are most likely better for health than SSBs. The few available studies suggest that higher prices of SSBs may lead to modest reductions in weight in the population. This evidence and the link between obesity and SSBs and its health outcomes should be sufficient for policy makers to consider SSB taxation as part of a package of intervention designed to reduce the health and economic burden due to obesity. Future research should address the consequences of a tax on SSBs, including the health gains, population affected and the impact on the macroeconomic environment including jobs, monetary savings to the health sector, implementation costs and revenue generated for the government [68]. Full cost-effectiveness studies would provide stronger evidence and allow policy makers to weigh these factors. To enhance relevance for any particular jurisdiction, such studies should use data specific to the countries or sub-regions, and be undertaken with sound understanding of contextspecific policies, history and socio-cultural preferences.

\section{Abbreviations}

SSBs: Sugar sweetened beverages; LMICs: Low and middle income countries; NCDs: Non-communicable diseases; HICs: High income countries; GBD: The Global Burden of Disease; NBER: National Bureau of Economics Research; RePEc: Research Papers in Economics.

\section{Competing interests}

The authors have declared that no competing interests exist. The content of the work presented here is solely the responsibility of the authors and does not necessarily represent the official views of the IDRC.

\section{Authors' contributions}

MC: Performed the literature review and prepared the first draft of the manuscript. LV: Supervised the meta-analysis and provided comments on all drafts of the manuscript. ST: Provided comments on the manuscript and critically revised it for important intellectual content. MB: Contributed to the conception of the study, supervised the initial literature review and provided critical comments on several draft of the manuscript. KH: Made substantial contributions to the conception of the study, provided critical comments to all drafts. All authors have given final approval of the manuscript to be submitted.

\section{Acknowledgments}

We wish to acknowledge the support of Patrizia Favini in preparing the manuscript.

\section{Funding}

This research was supported by grant PROP020911E from the IDRC, Canada. The funders had no role in study design, data collection and analysis, decision to publish, or preparation of the manuscript.

\section{Author details}

${ }^{1}$ PRICELESS SA (Priority Cost Effective Lessons in System Strengthening South Africa), Johannesburg, South Africa. ${ }^{2}$ School of Population Health, The University of Queensland, Brisbane, Australia. ${ }^{3}$ Wits/Medical Research Council Rural Health and Health Transitions Unit, School of Public Health, Faculty of Health Sciences, University of Witwatersrand, Johannesburg, South Africa.

Received: 30 April 2013 Accepted: 23 October 2013

Published: 13 November 2013

\section{References}

1. World Health Organization: Report of a Joint WHO/FAO Report. Diet, Nutrition and the Prevention of Chronic Diseases. Geneva: WHO technical report; 2002.

2. James WPT: WHO recognition of the global obesity epidemic. Int J Obes (Lond) 2008, 32(S7):S120-S126.

3. Malik VS, Willett WC, Hu FB: Global obesity: trends, risk factors and policy implications. Nat Rev Endocrinol 2013, 9(1):13-27.

4. Swinburn BA, Sacks G, Hall KD, McPherson K, Finegood DT, Moodie ML, Gortmaker SL: The global obesity pandemic: shaped by global drivers and local environments. Lancet 2011, 378(9793):804-814.

5. Chaput JP, Tremblay A: Obesity and physical inactivity: the relevance of reconsidering the notion of Sedentariness. Obes Facts 2009, 2:249-254.

6. Lim SS, Vos T, Flaxman AD, Danaei G, Shibuya K, Adair-Rohani H, AlMazroa MA, Amann M, Anderson HR, Andrews KG, Aryee M, Atkinson C, Bacchus LJ, 
Bahalim AN, Balakrishnan K, Balmes J, Barker-Collo S, Baxter A, Bell ML, Blore JD, Blyth F, Bonner C, Borges G, Bourne R, Boussinesq M, Brauer M, Brooks P, Bruce NG, Brunekreef B, Bryan-Hancock $C$, et al: A comparative risk assessment of burden of disease and injury attributable to 67 risk factors and risk factor clusters in 21 regions, 1990-2010: a systematic analysis for the Global Burden of Disease Study 2010. Lancet 2012, 380(9859):2224-2260.

7. Renehan AG, Tyson M, Egger M, Heller RF, Zwahlen M: Body-mass index and incidence of cancer: a systematic review and meta-analysis of prospective observational studies. Lancet 2008, 371(9612):569-578.

8. Guh $\mathrm{D}$, et al: The incidence of co-morbidities related to obesity and overweight: a systematic review and meta-analysis. BMC Public Health 2009, 9(1):88.

9. Goedecke JH, Jennings CL, Lambertc EV: Obesity in South Africa, Chronic diseases of lifestyle in South Africa since 1995-2005. South Africa: UCT/MRC Research Unit for Exercise Science and Sports Medicine, Department of Human Biology, Faculty of Health Sciences, University of Cape Town.

10. Mayosi BM, Flisher AJ, Lalloo UG, Sitas F, Tollman SM, Bradshaw D: The burden of non-communicable diseases in South Africa. Lancet 2009, 374(9693):934-947.

11. Holt E: Hungary to introduce broad range of fat taxes. Lancet 2011, 378(9793):755

12. Fletcher MJ, Frisvold DE, Tefft N: Can soft drink taxes reduce population weight? Contemp Econ Policy 2010, 28(1):23-35.

13. Rolls BJ, Drewnowski A, Ledikwe JH: Changing the energy density of the diet as a strategy for weight management. J Am Diet Assoc 2005, 105(5):98-103.

14. Stuckler D, Marion Nestle: Big food, food systems, and global health. PLoS Med 2012, 9(6):1-4.

15. Bateman C: Motsoaledi declares war on disease-causing products. $S$ Afr Med J 2011, 101(8):503-504.

16. Government notice, DoH: Foodstuffs, cosmetics and disinfectants act 1972 (Act 54 of 1972). Regulations relating to the reduction of sodium in certain foodstuffs and related matters. South Africa: Government Gazette. Department of Health; 2013:5

17. Pomeranz JL: Advanced policy options to regulate sugar-sweetened beverages to support public health. J Public Health Policy 2012, 33(1):75-88

18. Finkelstein EA, Zhen C, Bilger M, Nonnemaker J, Farooqui AM, Todd JE: Implications of a sugar-sweetened beverage (SSB) tax when substitutions to non-beverage items are considered. J Health Econ 2013, 32:219-239.

19. Hu F: Resolved: there is sufficient scientific evidence that decreasing sugar-sweetened beverage consumption will reduce the prevalence of obesity and obesity-related diseases. Obes Rev 2013, 8:606-619.

20. Ng SW, Mhurchu CN, Jebb SA, Popkin BM: Patterns and trends of beverage consumption among children and adults in Great Britain, 1986-2009. Br J Nutr 2011:1-6.

21. Caprio S: Calories from soft drinks - do they matter? N Engl J Med 2012, 367(15):1462-1463.

22. Novak NL, Brownell KD: Taxation as prevention and as a treatment for obesity: the case of sugar-sweetened beverages. Curr Pharm Des 2011 17(12):1218-1222.

23. Powell LM, Chriqui J, Chaloupka FJ: Associations between state-level soda taxes and adolescent body mass index. J Adolesc Health 2009, 45:S57-S63.

24. Yngve A, Haapala I, Hodge A, McNeill G, Tseng M: Making soft drinks the dietary version of the cigarette. Public Health Nutr 2012, 15(08):1329-1330.

25. French SA, Lin B-H, Guthrie JF: National trends in soft drink consumption among children and adolescents age 6 to 17 years: prevalence, amounts, and sources, 1977/1978 to 1994/1998. J Am Diet Assoc 2003, 103(10):1326-1331.

26. Terry-McElrath YM, O'Malley PM, Johnston LD: Factors affecting sugarsweetened beverage availability in competitive venues of US secondary schools. J Sch Health 2012, 82(1):44-55.

27. Malik VS, Schulze MB, Hu FB: Intake of sugar-sweetened beverages and weight gain: a systematic review. Am J Clin Nutr 2006, 84:274-288.

28. Vartanian $L R$, Schwartz MB, Brownell KD: Effects of soft drink consumption on nutrition and health: a systematic review and meta-analysis. Am J Public Health 2007, 97(4):667-675.

29. Qi Q, Chu AY, Kang JH: Sugar-sweetened beverages and genetic risk of obesity. N Engl J Med 2012, 367(15):1387-1396.

30. Hector D, Rangan A, Gill T, Louie J, Flood VM: Soft Drinks, Weight Status and Health: A Review. Sydney: A NSW Centre for Public Health Nutrition (now known as Cluster of Public Health Nutrition, Prevention Research Collaboration, University of Sydney) project for NSW Health; 2009.
31. Steyn NP, Myburgh NG, Nel JH: Evidence to support a food-based dietary guideline on sugar consumption in South Africa. Bull World Health Organ 2003, 81(8):599-608.

32. Ruyter JC, Olthof MR, Seidell JC, Katan MB: A trial of sugar-free or sugarsweetened beverages and body weight in children. N Engl J Med 2012, 367:1397-1406.

33. Leppo K, Ollila E, Pena S, Wismar M, Cook S: Health in all policies-seizing opportunities, implementing policies. Julkaisuja (STM) 2013, 9:2013.

34. Beaglehole R, Bonita R, Horton R, Adams C, Alleyne G, Asaria P, Baugh V, Bekedam H, Billo N, Casswell S, Cecchini M, Colagiuri R, Colagiuri S, Collins T, Ebrahim S, Engelgau M, Galea G, Gaziano T, Geneau R, Haines A, Hospedales J, Jha P, Keeling A, Leeder S, Lincoln P, McKee M, Mackay J, Magnusson R, Moodie R, Mwatsama M, et al: Priority actions for the non-communicable disease crisis. Lancet 2011, 377(9775):1438-1447.

35. Cecchini M, Sassi F, Lauer JA, Lee YY, Guajardo-Barron V, Chisholm D: Tackling of unhealthy diets, physical inactivity, and obesity: health effects and cost-effectiveness. Lancet 2010, 376(9754):1775-1784.

36. Sacks G, Veerman JL, Moodie M, Swinburn B: Traffic-light' nutrition labelling and 'junk-food' tax: a modelled comparison of costeffectiveness for xf obesity prevention. Int J Obes 2011, 35:1001-1009.

37. Powell L, Chriqui J, Khan T, Wada R, Chaloupka F: Assessing the potential effectiveness of food and beverage taxes and subsidies for improving public health: a systematic review of prices, demand and body weight outcomes. Obes Rev 2013, 14(2):110-128.

38. Andreyeva T, Long M, Brownell $K$ : The impact of food prices on consumption: a systematic review of research on the price elasticity of demand for food. J Inf 2010, 100:2

39. Case K, Fair RC: Principles of Economics. 4th edition. Upper Saddle River, New Jersey: Prentice Hall Inc; 1994

40. Browing E, Browing J: Microeconomic Theory and Application. 4th edition. Harper Collins Publishers Inc; 1992.

41. Thiele S: Fat Tax: A Political Measure To Reduce Overweight? The Case Of Germany. In 115th Joint EAAE/AAEA Seminar, September 15-17, 2010. Freising-Weihenstephan, Germany: European Association of Agricultural Economists; 2010:0-14

42. Dharmasena S, Capps O: Intended and unintended consequences of a proposed national tax on sugar-sweetened beverages to combat the $\mathrm{U}$. S. obesity problem. Health Econ 2012, 21(6):669-694.

43. Andreyeva T, Chaloupka FJ, Brownell KD: Estimating the potential of taxes on sugar-sweetened beverages to reduce consumption and generate revenue. Prev Med 2011, 52(6):413-416.

44. Barquera S, Hernandez-Barrera L, Tolentino ML, Espinosa J, Ng SW, Rivera JA, Popkin BM: Energy intake from beverages is increasing among Mexican adolescents and adults. J Nutr 2008, 138(12):2454-2461.

45. Bonnet $C$, Requillart $\mathrm{V}$ : Does the EU sugar policy reform increase added sugar consumption? An empirical evidence on the soft drink market. Health Econ 2011, 20(9):1012-1024.

46. Claro RM, Levy RB, Popkin BM, Monteiro CA: Sugar-sweetened beverage taxes in Brazil. Am J Public Health 2012, 102(1):178-183.

47. Finkelstein EA, Zhen C, Nonnemaker J, Todd JE: Impact of targeted beverage taxes on higher-and lower-income households. Arch Intern Med 2010, 170(22):2028-2034

48. Fletcher JM, Frisvold DE, Tefft $\mathrm{N}$ : The effects of soft drink taxes on child and adolescent consumption and weight outcomes. J Public Econ 2010, 94(11):967-974.

49. Lin BH, Smith TA, Lee YJ: Measuring weight outcomes for obesity intervention strategies: the case of a sugar-sweetened beverage tax. Econ Hum Biol 2011, 9:329-341.

50. Smith TA, Lin BH, JY L: Taxing Caloric Sweetened Beverages: Potential Effects on Beverage Consumption, Calorie Intake, and Obesity. In ERR-100. Edited by Economic Research Service. USA: U.S. Department of Agriculture; 2010:1-25.

51. Gordon-Larsen P, Guilkey DK, Popkin BM: An economic analysis of community-level fast food prices and individual-level fast food intake: a longitudinal study. Health Place 2011, 17(6):1235-1241.

52. Han E, Powell LM: Effect of food prices on the prevalence of obesity among young adults. Public Health 2011, 125:129-135.

53. Pan A, Malik VS, Hao T, Willett WC, Mozaffarian D, Hu FB: Changes in water and beverage intake and long-term weight changes: results from three prospective cohort studies. Int J Obes (Lond) 2013, 10:1378-1385. 
54. Veitch J, Singh A, van Stralen MM, Van Mechelen W, Brug J, ChinAPaw Mai $J M$ : Reduction in sugar-sweetened beverages is not associated with more water or diet drinks. Public Health Nutr 2010, 14(8):1388.

55. Dhingra R, Sullivan L, Jacques PF, Wang TJ, Fox CS, Meigs JB, D'Agostino RB, Gaziano JM, Vasan RS: Soft drink consumption and risk of developing cardiometabolic risk factors and the metabolic syndrome in middleaged adults in the community. Circulation 2007, 116(5):480-488.

56. Ribaudo $M$, Shortle J: Can taxing sugary soda influence consumption and avoid unanticipated consequences? In The magazine of food and resource issue. vol. 2013. 2011

57. Ebbeling CB, Feldman HA, Chomitz VR: A randomized trial of sugar-sweetened beverages and adolescent body weight. N Engl J Med 2012, 367(15):1407-1415.

58. Brownell KD, Frieden TR: Ounces of prevention - the public policy case for taxes on sugared beverages. N Engl J Med 2009, 360(18):1805-1807.

59. Wilson N, Thomson G, Blakely $\mathrm{T}$ : Use of pricing and tax interventions for protecting health: potential relevance for New Zealand of recent international developments. N Z Med J 2011, 124(1342):100-103.

60. Chriqui JF, Chaloupka FJ, Powell LM, Eidson SS: A typology of beverage taxation: multiple approaches for obesity prevention and obesity prevention-related revenue generation. J Public Health Policy 2013, 3:403-423.

61. Perez AM, Ayo-Yusuf OA, Hofman K, Kalideen S, Maker A, Mokonoto D, Morojele N, Naidoo P, Parry C, Rendall-Mkosi K: Establishing a health promotion and development foundation in South Africa. S Afr Med J 2013, 103(3):147-149.

62. Epstein L, Dearing K, Paluch R, Roemmich J, Cho D: Price and maternal obesity influence purchasing of low-and high-energy-dense foods. Am J Clin Nutr 2007, 86(4):914-922.

63. Klonoff DC: A sweetened beverage tax is needed to combat the obesity epidemic as well as related absenteeism and presenteeism. J Diabetes Sci Technol 2009, 3(3):408-410.

64. Powell L, Chaloupka FJ: Food prices and obesity: evidence and policy implications for taxes and subsidies. Milbank Q 2009, 87(1):229-257.

65. Puoane T, Bradley H, Hughes GD: Obesity among black South African women. Hum Ecol 2005, 13(Special Issue):91-95.

66. Ali AT, Crowther NJ: Factors predisposing to obesity: a review of the literature. JEMDSA 2009, 14(2):81-84.

67. Ziraba AK, Fotso JC, Ochako R: Overweight and obesity in urban Africa: a problem of the rich or the poor? BMC Public Health 2009, 9(465):1-9.

68. Smith $\mathrm{R}$ : Why a macroeconomic perspective is critical to the prevention of noncommunicable disease. Science 2012, 337(6101):1501-1503.

doi:10.1186/1471-2458-13-1072

Cite this article as: Cabrera Escobar et al:: Evidence that a tax on sugar sweetened beverages reduces the obesity rate: a meta-analysis. BMC Public Health 2013 13:1072.

\section{Submit your next manuscript to BioMed Central and take full advantage of:}

- Convenient online submission

- Thorough peer review

- No space constraints or color figure charges

- Immediate publication on acceptance

- Inclusion in PubMed, CAS, Scopus and Google Scholar

- Research which is freely available for redistribution 